\title{
Aldarafmæli spænsku veikinnar og viðbrögð við skæðum farsóttum á 21. öld
}

Í pessum mánuði minnumst við pess að 100 ár eru liðin frá pví að spænska veikin kom til Íslands, en önnur bylgja veikinnar barst til Reykjavíkur með farpegum Botníu pann 20. október 1918. Spænska veikin er einn stærsti hörmungaratburður í nútíma mannkynssögu. Talið er að 50-100 milljónir manna hafi týnt lífi í hinum premur bylgjum veikinnar sem riðu yfir heimsbyggðina árin 1918-1919, - margfalt fleiri en létust vegna heimsstyrjaldarinnar fyrri. Ef tekið er tillit til mannfjöldapróunar í heiminum jafngildir petta 200-425 milljónum dauðsfalla nú. Dánartíðni var nokkuð breytileg eftir löndum, á bilinu 2-25\%, og var langhæst par sem ekkert ónæmi fyrir veirunni var til staðar.

Í tilefni pessa endurbirtir Læknablaðið hina frábæru grein Pórðar Thoroddsens læknis, sem birtist á síðum blaðsins í premur hlutum fyrri hluta ársins 1919. Í fyrri hluta greinar sinnar gefur Pórður sögulegt yfirlit yfir inflúensufaraldra fyrri alda hérlendis og í seinni hlutanum fjallar hann sérstaklega um spænsku veikina í Reykjavík, en hann stóð sjálfur í hringiðu atburðanna og fylgdist með gangi veikinnar, sinnti 1232 sjúklingum og var svo heppinn að halda heilsu allan tímann. Pórður náði að halda ótrúlega nákvæma skrá um eðli faraldursins í borginni, einkenni skjólstæðinga sinna og afdrif peirra, margt samhljóða pví sem erlendir kollegar hans lýstu. Grein Pórðar er rituð af fádæma skarpskyggni og yfirsýn manns sem greinilega var eigi einhamur. Sérstaka athygli vekur að peir sem veiktust í fyrstu bylgjunni sem barst til landsins sumarið 1918 sluppu við drepsóttina sem hélt innreið sína í október, en einnig að ungt fólk, 20-40 ára veiktist oft alvarlega með gríðarlega svæsinni lungnabólgu og öndunarbilun; dánartíðnin var hæst í peim hópi, andstætt pví sem almennt gildir um flestar sýkingar. Pá urðu barnshafandi konur illa úti, - nokkuð sem hefur komið ítrekað í ljós í seinni tíma inflúensufaröldrum. Í tvennum skilningi eru viðbrögð borgarbúa og landsmanna allra við pessum vágesti einnig eftirtektarverð og lærdómsrík, - stofnun hjúkrunarnefndarinnar, - samstaða og samhjálp borgarbúa og frumkvæði að einangrun Norður- og Austurlands. Sú ráðstöfun varð til pess að allstór hluti landsmanna slapp við veikina í pessari atlögu, en flestir urðu pó fyrir barðinu á henni síðar. Læknisfræði pessa tíma bauð ekki upp á sértæka meðferð enda var inflúensuveiran ennpá ópekkt árið 1918. Súrefnisgjöf og sýklalyf til að meðhöndla fylgisýkingar stóðu ekki til boða. Spænska veikin markaði djúp spor í minni aldamótakynslóðarinnar sem endurómaði nánast alla 20. öld og hafði margvísleg áhrif, varð meðal annars kveikjan að pví að ný lög um sóttvarnaráđstafanir voru sampykkt árið 1923. Engu að síður má pað teljast merkilegt hversu lítið aðrar afleiðingar veikinnar hafa verið rannsakaðar, til dæmis áhrif á pá sem misstu sína nánustu, en sögurnar um pað lifa enn innan margra fjölskyldna.

Pegar litið er um öxl nú, árið 2018, er fátt á Íslandi sem minnir á stöðu landsins 1918. Landið er orðið eitt hið auðugasta í heimi, íbúafjöldinn hefur nær fjórfaldast á öldinni sem liðin er, efnahagsleg velmegun er almenn og íbúar landsins hafa fjölbreyttari bakgrunn en áður var, samgöngur við útlönd eru svo góðar að segja má að landið sé sítengt umheiminum. Sú vörn gegn smitsjúkdómum sem áður fólst í einangrun landsins er löngu fyrir bí. Íslendingar purfa pví að vera undir pað búnir rétt eins og aðrir að hingað berist alvarlegir smitsjúkdómar sem geta breiðst hratt út. Dæmi um sjúkdóma sem geta hagað sér með peim hætti eru Ebola, skæðar sýkingar af völdum Coronaveira og nýir stofnar inflúensu. Alpjóðaheilbrigðisstofnunin WHO hefur sett pessa sjúkdóma í sérstakan forgang og nýlega bætt við „sjúkdómi X“ til að minna pá sem bera ábyrgð á undirbúningi og viðbragðsáætlunum á pað að stærsta ógnin kunni enn að vera með öllu ópekkt, sjúkdómsvá sem kemur okkur algerlega á óvart.

Reynslan af hinum tiltölulega væga inflúensufaraldri 2009 og síðari tíma farsóttum sýnir að við erum furðulega illa undir slíka vágesti búin í margvíslegu tilliti. Nægir par að benda á að aðstaða til einangrunar og fjöldi rúma á gjörgæsludeildum hérlendis er ófullnægjandi eins og nýlega hefur verið bent á hér í blaðinu. Í venjulegu árferði er spítali allra landsmanna iðulega yfirfullur og pví knúinn til að lýsa yfir viðbúnaðarstigi vegna minni háttar aukningar á álagi. Aðrir veikleikar hjá okkur lúta að takmörkuðu birgðahaldi margra helstu nauðsynja og má par nefna bæði lífsnauðsynleg lyf og ýmsa einnota hluti sem notaðir eru í meðferð fjölveikra. Á pessu parf að gera bragarbót. Árið 2018 hljótum við að geta gert betur.

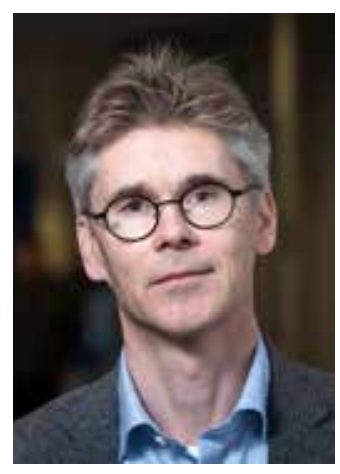

\section{Magnús Gottfreðsson}

sérfræðingur í lyflækningum og smitsjúkdómum, yfirlæknir við Landspítala og prófessor við læknadeild Háskóla Íslands.

Ritstjóri Læknablaðsins.

magnusgo@landspitali.is

\section{Spanish flu centennial and responses to pandemic threats in the $21^{\text {st }}$ century}

Magnus Gottfredsson, MD, PhD, FACP, professor, Landspitali University Hospital and Faculty of Medicine, School of Health Sciences, University of Iceland.

doi.org/10.17992/lbl.2018.10.198 